\title{
Patterns and Problems of Information Use in the Production of Articles by Academics in the Humanities and Social Sciences in Thailand
}

\author{
Chumchit Saechan ${ }^{1}$ \\ ${ }^{1}$ Department of Library and Information Science, Faculty of Humanities and Social Sciences, Prince of Songkla \\ University, Thailand \\ Correspondence: Chumchit Saechan, Department of Library and Information Science, Faculty of Humanities and \\ Social Sciences, Prince of Songkla University, 94000, Thailand. Tel: 66-8-1543-3556. E-mail: \\ schum@bunga.pn.psu.ac.th
}

Received: January 16, 2014

Accepted: March 20, 2014 Online Published: April 29, 2014

doi:10.5539/ass.v10n9p115

URL: http://dx.doi.org/10.5539/ass.v10n9p115

\begin{abstract}
This study aimed to analyze the patterns of the use of information by academics in the humanities and social sciences in Thailand when producing academic articles, and to study and compare the problems encountered in their use of information based on the variables: gender, age, education, academic role and discipline. Citation analysis includes 3,464 citations from 203 articles in six qualified journals indexed in the Thai Citation Index Centre and international databases. A survey research using a questionnaire was sent to 203 academics who had published articles in the selected journals. The statistics for data analysis were frequency, percentage, range, t-test, and F-test. The key findings showed that the most widely used sources were books, journals, master's theses, $\mathrm{PhD}$ dissertations, websites, newspapers, research reports, interviews, proceedings, and lecture notes. They preferred single-author works published within the last 10 years. The average to publish one article, the researcher used approximately 18 citations. The problems of information use encountered included those related to information resource centers/libraries, the academics in the humanities and social sciences themselves, humanities and social sciences information, and publisher, all of which were at a moderate level. However, there were problems at a high level in respect of information resources, and the staff of the information resource centers/libraries, and also in respect of the users being able to think of search terms, using library tools, and evaluating information.
\end{abstract}

Keywords: humanities and social sciences, humanities academics, information use, information use problems, social scientists

\section{Introduction}

\subsection{Problems and Significance}

Scientific and technological advances have altered all aspects of life, and technological progress has not only changed mankind's lifestyles but also the way that people think, and organize their societies. These changes make today societies confronting many problems and more complexities. While knowledge in the disciplines of science and technology is developed to solve sickness and the inconvenience of mankind, knowledge in the humanities and social sciences is also important in investigating the economic and social problems. However, the humanities study human values and relationships between people, their creativity and imagination, their spirituality, intelligence and idealism, their sense of goodness, and the insights they have (Imroth, 1974). On the other hand social sciences explore human relations in society and human behavior (Srisawat, 2009; Changkwanyeun, 1895). Knowledge gained from pure/theoretical research, institutional research and policy research helps the creation of new knowledge, and the solution of organizational and operational problems as well as the economic and social planning and development of the country (Kiranan, 2001).

Currently, there is a great need for knowledge in the humanities and social sciences to help to solve problems and to understand people in complex modern societies. In Thailand, there is still a big gap between the information produced in science and technology, and that produced in the humanities and social sciences. In particular when compared with science and technology, those involved in the humanities and social sciences 
obviously have access to far fewer publications and these are of lower quality, and less widely available (Reuwongsa, 1995). The Thailand Citation Index Centre (TCI) (2010) reported information on journal use based on citations from 194 humanities and social sciences journals selected in its database and found that internationally only 4 journals are indexed in 4 international databases (ERIC, Popline, Scopus, AGRIS) whereas there are 191 science and technology journals recorded in the TCI database, 29 of which are indexed in 12 international databases, (AgBiotechnet, Scopus, AGRIS, PubMed, WoS, Scifind, CINNAL, CAPLUS, Zoological Record, Biological Abstract, Euktronische Zetchriftenbibliothek, Zentralblatt Math).

Information is one of the most important factors affecting the production of literature by academics. The availability of information is a crucial issue for academics who wish to explore, expand, and share knowledge with their colleagues at a national and international level. Before selecting an appropriate research topic/title, academics in the humanities and social sciences need to review the existing literature in order to familiarize themselves with knowledge relevant to their field of study, and to know its history and development. Study of the literature will integrate and consolidate knowledge and allow academics to learn from the work of other academics which will in turn stimulate new ideas (Thirasorn, 2009; Srisawat, 2009). Suebson (1989) classified the use of information according to four areas or objectives: use for personal needs, use for education and learning, use for career and working performance and use for information transfer. These four areas lead to different methods for searching for and using information. According to Wilson (1999), the behaviors of those seeking information vary according to age, gender, level of education, discipline and their career.

There are still problems of the sufficiency, quality, availability, and use of information related to the humanities and social sciences. Production of qualified articles from academics in the humanities and social sciences needs the help of the information professionals to provide information services to meet their needs of these particular disciplines. A review of the literature in Thai suggests that there have been few studies and reports of the needs and behaviors of users in the humanities and social sciences in regard to information services as compared to those engaged in science and technology. Therefore, this study will provide data about the information seeking behavior of academics in the humanities and social sciences as well as their characteristics, and the problems they encounter in the use of information. Ultimately, education and research in the humanities and social sciences should contribute to the strengthening of unity, the involvement of individuals in society, social harmony, honesty, individual creativity, and they should help the development of the country as a whole.

\subsection{Literature Review}

Citation analysis is a well-established procedure for examining knowledge exchange Garfield, 1979). It allows the contributions of disciplines, journals, articles, and scholars to be evaluated by giving substantive expression to the use and diffusion of knowledge. Most of the past research in this field might be better termed "reference analysis" since the unit of analysis has historically been references rather than citations. Citation analysis is also a way to understand users. Studying references cited by faculty's publications or students' papers shows the types of sources most common used and valued locally in their disciplines (Curtis, 2005).Citation analysis is a relatively straightforward tool for librarians to use to better understand their users or analyze their collections. This technique used in variety of disciplines, for example; medical sciences (Siamian et al., 2007), agriculture (Dulle et al., 2004), civil and building construction (Ahmadzadeh, 2004), forestry,(Brazzeal \& Fowler, 2005), pharmacy (Choinski, 2007), chemistry (Ortega, 2008).

In humanities and social sciences, Zainab and Goi (1997) analyzed the characteristics of citations used by postgraduate students in the humanities (religion and philosophy; history; language and literature) based on the dissertations submitted to the University of Malaya between 1984 and 1994. They found that the preferred language was Malay (61\%) followed by English. Their study supported that books were cited the highest (52\%) followed by journal articles $(23.55 \%$ ), and $6.24 \%$ to theses. Authorship pattern for the citation showed that single author dominated. Khosrojerdi (2005) in a citation study of MA psychology dissertations in Tehran University showed that the favorite source was $74.6 \%$ periodicals followed by $13.2 \%$ books. The major language of resources was English (67.9\%) followed by Persian (21\%). Zandian et al. (2007) performed a citation analysis of the PHD arts and humanities dissertations in Tarbiat Modares University. They reported printed materials citations at $96 \%$, and book citations at $92.86 \%$. Persian resources received $60.1 \%$ of total citations followed by English 19.2\% and Arabic 20.6 \%. Chikate and Patil (2008) studied theses in library and information science submitted to University of Pune. More than 6,000 citations from 27 doctoral dissertations were analyzed. The researcher found that nearly half of the citations recorded are from journals $(42.2 \%)$, and nearly three quarters of the journal articles were from LIS journals, with the remainder from 33 other subject areas. 
Beside using citation analysis technique for data collection, many survey research performed about information usage characteristics in humanities and social sciences. Fidzani (1998) explored graduate students' information-seeking behavior and their awareness of library resources at the University of Botswana. Based on the results, suggests that many graduate student lack basic skills in effectively using the library and its resources. Delgadillo and Lynch's study of history graduate students (1999) conclude that graduate students in history tend to demonstrate the same information-seeking patterns as faculty historians. There is an ample body of literature on the information-seeking behavior of humanist scholars in general. Several studies and reviews of literature (Weintraub, 1980; Garfield, 1980; Stone, 1982; Watsan-Boone, 1994) confirm the nature of humanities scholarship, the significance of the library as the humanists' laboratory, their preferences for monographs and original materials, serendipitous information retrieval patterns, a reliance on personal contacts as well as private collections, and a guarded approach to information technology.

\subsection{Objectives}

The objectives of this research project were to: 1) Investigate the information use patterns of academics in the humanities and social sciences in Thailand 2) Identify problems encountered by academics in the humanities and social sciences in using information to produce articles in Thailand and 3) Compare the problems encountered by academics in the humanities and social sciences in using information to produce articles based on the variables: gender, age, level of education, academic title, and discipline.

\subsection{Hypothesis}

Academics in the humanities and social sciences in Thailand who vary in gender, age, education, academic role, and discipline will have different problems relating to information use in producing academic articles.

\subsection{Limitations}

This research studied six journals in humanities and social sciences, covered a period of two years but due to the delay of publishing on time in some journals, the year of journals for data collection is late to year 2008-2009. Data is collected from the first or correspondent author and it is limited to author with Thai nationality.

\section{Methodology}

\subsection{Citation Analysis}

Document research methodology for empirical data was applied by analyzing citations from 203 articles published in six academic journals indexed by the Thai Citation Index Centre (TCI) and international database. The study covered a period of two years of publication. The journals were selected based on the criterion that they had all volume and number of articles published within the year of this study conducted. The six journals were divided into three groups: two humanities journals, two social science journals, and two journals that publish articles on both the humanities and social sciences. The statistics for data analysis were frequency, percentage, and range.

Citation analysis was performed on a total of 3,464 citations from the reference sections/bibliographies of all articles, including research articles, reviewed articles, and book reviews. Analyses were conducted with spreadsheets and SPSS according to the objectives of the study. Data were collected from in-text citations, footnotes, and reference sections/bibliographies. The following data were collected: number of authors, documents cited by year/volume/issue, type, language, and number of citations/references per article.

\subsection{Survey Method}

A survey conducted using a questionnaire consisting of 3 parts: 1) participant's status, 2) information use characteristics, and 3) problems and obstacles encountered in using information. Three experts in the field of library and information science, the humanities and social sciences checked the content validity and reliability of the questionnaire.

The questionnaire was used to collect data from 203 academics in the humanities and social sciences who had published articles from the citation analysis. Due to the limitations arising from the incomplete provision of contact information of the authors provided in the journals, only 110 academics in the humanities and social sciences were able to be contacted. A total of 88 questionnaires $(80 \%)$ were returned and the information provided was recorded in a spreadsheet and further analyzed using the SPSS computer program in accordance with the objectives of the study. The statistics used for the data analysis were the frequency, percentage, mean, and standard deviation, and the tests employed to establish the significance of variations in the data were t-tests, F-tests, and Scheffe tests. 


\section{Results and Discussion}

\subsection{Results from Citation Analysis \\ 1) Journal data}

The journals selected as the sample were journals listed in the Thailand Journal Citation Index Centre (TCI) database, and four of them are also indexed in the international databases, ERIC, Scopus, Popline and AGRIS. The journals selected were published between the years 2008 and 2009. Two dealt with the humanities, namely PASSA, and Manusaya, and two dealt with the social sciences, namely the Journal of Population and Social Studies, and the Journal of Sciences, KU. Two dealt with both areas, namely the Songklanakarin Journal of Social Sciences and Humanities and the Journal of Humanities and Social Sciences, KKU. These journals vary in their frequency of publication, ranging from between one and six editions per year and 8-12 articles per journal. (see Table 1)

Table 1. Details of journals

\begin{tabular}{|c|c|c|c|c|}
\hline \multirow[t]{2}{*}{ Discipline } & \multirow[t]{2}{*}{ Language } & \multirow{2}{*}{$\begin{array}{l}\text { Frequency } \\
\text { /year }\end{array}$} & \multicolumn{2}{|c|}{ Database } \\
\hline & & & national & international \\
\hline \multicolumn{5}{|l|}{ Humanities } \\
\hline 1. PASSA & English* & 1 & TCI & ERIC \\
\hline 2. Manusaya & English* & 2 & TCI & Scopus \\
\hline \multicolumn{5}{|l|}{ Social sciences } \\
\hline 3. J. of Population and Social Studies & English* & 2 & $\mathrm{TCI}$ & Popline \\
\hline 4. J. of Sciences, KU & Thai** & 3 & TCI & Scopus \\
\hline \multicolumn{5}{|l|}{ Humanities \& Social sciences } \\
\hline $\begin{array}{l}\text { 5. Songklanakarin J. of Social } \\
\text { Sciences and Humanities }\end{array}$ & Thai** & $4-6$ & TCI & \\
\hline $\begin{array}{l}\text { 6. J. of Humanities and Social } \\
\text { Sciences ,KKU }\end{array}$ & Thai** & 3 & $\mathrm{TCI}$ & \\
\hline
\end{tabular}

2) Citation characteristics

Table 2. Maximum and minimum number of citations

\begin{tabular}{llll}
\hline Citation & Frequency & & \\
\hline & Maximum & Minimum & Average \\
\hline In-text citation & 47 & 1 & 22 \\
Footnote & 27 & 1 & 2 \\
Reference & 82 & 1 & 18 \\
\hline
\end{tabular}

The average article included 22 in-text citations, two footnotes/endnotes, and 18 references.

These results showed that humanities academics and social scientists used many sources of information in order to create each article. Reference citations were the most common, while footnotes/endnotes were the least common (reference $\max =82$, footnote $\max =27$ ). This suggests that research in the humanities and social sciences is descriptive and content analysis-based. The authors often used indirect citations, which implies that they might have had problems finding information in primary sources (see Table 2). 


\section{3) Format of information resources}

Most of the information sources cited were books $(55.10 \%)$. This result is noteworthy in that it is consistent with the results of many previous studies (Marouf \& Anwar, 2010; Meho \& Hass, 2001; Popoola, 2008; De Tiratel, 2000). Previous studies found that authors cited monographs and original sources (Meho \& Hass, 2001; Rimmer, Warwick, Blandford, Gow, \& Buchanan, 2006; Sherriff, 2010), along with abstracts and indexes, personal correspondence with colleagues, statistical documents, meeting documents, and textbooks (Popoola, 2008).

Authors tend to prefer printed materials over audio-visual materials (Tahir \& Mahmood, 2008). Sherriff (2010) reported that the predominant format in history research is the monograph. Because historical research entails the use of older resources, journal usage is low compared to other disciplines. These findings are relevant to the current study because books are readily available and typically easier to access than other formats. In general, however, information in book format is not as current as information published in journals. This research found that most sources used by Thai humanities academics and social scientists were written in the Thai language. These findings point to a lack of knowledge exchange and a failure to expand research to include academics from other parts of the world.

The remaining $45 \%$ of information sources cited included journals $(25.60 \%)$, master's theses $(7.70 \%), \mathrm{PhD}$ dissertations $(1.60 \%)$, and websites $(6.70 \%)$ (see Table 3 ). Comparing the percentages of this finding, it obviously sees that number of website citations is growing. It indicates a positive trend of using websites based on convenience, ease of use, availability, and accessibility. This is relevant to Haridasan, Sudharma, Khan, \& Majid's (2009) study on the impact and use of e-resources by social scientists at India's National Social Science Documentation Centre. The authors found that social scientists recognized the importance of e-resources, especially e-books, e-journals, e-encyclopedia, e-theses, CD-ROM databases, email, the internet, and Online Public Access Cataloguing (OPAC) (Haridasan, Sudharma, Khan, \& Majid's, 2009). However, information professionals should be aware that academics in the humanities and social sciences may be less familiar with e-resources than academics in the natural sciences and technology-based disciplines. As Smith (2003) reported, physical science professors are more likely than social science professors to read articles in e-journals.

Table 3. Format of information resources

\begin{tabular}{lll}
\hline Format & Frequency & Percentage \\
\hline Book & 1910 & 55.10 \\
Journal & 871 & 25.60 \\
Theses & 322 & 9.30 \\
-MA & 267 & 7.70 \\
-PhD & 55 & 1.60 \\
Website & 232 & 6.70 \\
Research report & 34 & 1.00 \\
Newspaper & 18 & 0.50 \\
Interview & 10 & 0.30 \\
Lecture, seminar notes, etc. & 67 & 1.90 \\
Total & 3464 & 100.00 \\
\hline
\end{tabular}

Humanities academics and social scientists have indicated that they are not always able to find the information they require (Tahir \& Mahmood, 2008). They have also reported a lack of information resources in books and journals (De Tiratel, 2000) and struggled with poor-quality information (Marouf \& Anwar, 2010). Marouf and Anwar found that social scientists seldom use library services due to the poor quality of the librarians and the libraries' lack of resources (2010). Rimmer, Warwick, Blandford, Gow, and Buchanan's (2006) findings indicated that humanities academics and social scientists had difficulty using advanced electronic search tools available in libraries. De Tiratel (2000) found that humanities academics had difficulty locating resources and finding information. 
4) Authorship patterns of citations

Table 4. Authorship patterns of citations in humanities and social sciences articles

\begin{tabular}{lll}
\hline Number of authors & Frequency & Percentage \\
\hline 1 & 2595 & 74.90 \\
2 & 457 & 13.20 \\
3 or more & 289 & 8.30 \\
N/A & 123 & 3.50 \\
Total & 3464 & 100.00 \\
\hline
\end{tabular}

Single-author articles were cited most often (74.90\%), followed by articles by two authors $(13.20 \%)$, three or more authors $(8.30 \%)$, and no details about the authors $(3.50 \%)$ (see Table 4$)$. This finding suggests that academics within the humanities and social sciences prefer to publish single-author articles. It can be assumed that humanities academics and social scientists like to work alone.

5) Language of cited documents

Table 5. Language of cited documents

\begin{tabular}{lll}
\hline Language & Frequency & Percentage \\
\hline Thai & 1896 & 54.74 \\
English & 1061 & 30.62 \\
German & 211 & 6.10 \\
French & 206 & 5.94 \\
Other & 90 & 2.60 \\
Total & 3464 & 100.00 \\
\hline
\end{tabular}

Most of the articles cited were written in the Thai language (54.74\%), and a large number of articles were written in English (30.62\%). Smaller proportions of articles were written in German (6.10\%), French (5.94\%), and other languages including Chinese, Malaysian, Burmese, and Khmer (2.60\%). It is not surprising that most authors wrote in their native language, especially considering that some humanities articles focused on Thai language, Thai literature, or Thai history. These publications are published nationally. This trend aligns with previous research indicating that publications from developing countries have difficulty attracting international attention (Arunachalam, 2003; Baird \& Oppenheim, 1994; Chan et al., 2005; Guan \& Mo, 2004).

English was the most popular foreign language, followed by German and French. There were some articles written in Asian languages such as Chinese, Malaysian, Burmese, and Khmer. This implies that humanities academics and social scientists are turning their attention to countries that will be included in the ASEAN Economic Community in 2015 (Thailand, Malaysia, Lao, Cambodia, Myanmar, Indonesia, Singapore, Vietnam, Brunei Darussalam, Philippines) (see Table 5). 
6) Cited documents' place of publication

Table 6. Cited documents' place of publication

\begin{tabular}{llc}
\hline Ranking & Item & Number \\
\hline Thai language & & \\
1 & Bangkok & 49 \\
2 & Nakorn Prathom & 8 \\
3 & Nontaburi & 6 \\
4 & Chiang Mai & 3 \\
5 & Pitsanulok & 2 \\
English language & & \\
1 & New York & 25 \\
2 & London & 12 \\
3 & Hanoi & 5 \\
4 & Chicago, IL & 5 \\
5 & Boston, MA & 4 \\
\hline
\end{tabular}

Most Thai publications were printed in Bangkok, followed by the metropolitan areas of Nakorn Prathom and Nontaburi and the large cities of Chiang Mai and Pitsanulok. New York was the most popular place of publication among foreign articles, followed by London, Hanoi, Chicago, and Boston. It is noteworthy that most foreign print publications hailed from the United States (see Table 6). Most Thai publications are printed by the government, whereas most foreign publications are published by the private sector.

Humanities academics and social scientists favored documents published within the last 10 years (between 1997 and 2008). The oldest document cited was printed in 1650, while the most recent document cited was published in 2008 .

\subsection{Results from Survey Research}

1) Sample data

The participants in this research were 88 academics in the humanities and social sciences, most of whom actively published articles in the journals in this study. The sample was composed of 48 females (54.50\%), and 40 males $(45.60 \%)$ the largest group of whom were aged above 50 years $(39.80 \%)$, and whose level of education was $\mathrm{PhD}$. $(64.80 \%)$. The academic role of the largest number was assistant professor (37.50\%). Of the two disciplines, the social sciences accounted for $67.00 \%$ of the participants (see Table 7). Almost all of them worked in educational institutions $(95.50 \%)$, with the remainder split between other government organizations $(3.40 \%)$, and the private section $(1.10 \%)$ (see Table 8$)$. 
Table 7. Demographic variables of the research participants

\begin{tabular}{lll}
\hline Variable & Number & Percentage \\
\hline Gender & & \\
female & 48 & 54.50 \\
male & 40 & 45.50 \\
Age & & \\
$20-30$ & 2 & 2.30 \\
$31-40$ & 29 & 33.00 \\
$41-50$ & 22 & 25.00 \\
$>50$ & 35 & 39.70 \\
Education & & \\
Bachelor's degree & 2 & 2.30 \\
Master's degree & 27 & 30.70 \\
PhD & 57 & 64.80 \\
$>$ PhD & 21 & 2.20 \\
Academic role & & \\
lecturer & 21 & 23.90 \\
assist. prof. & 33 & 37.50 \\
assoc. prof. & 23 & 26.00 \\
professor & 5 & 5.60 \\
others & 8 & 9.00 \\
Discipline & 58 & 26.10 \\
humanities & 23 & 67.00 \\
social sciences & 59 & 6.90 \\
others (nursing science, etc.) & 600.00 \\
Total & &
\end{tabular}

Table 8. Employment of the research participants

\begin{tabular}{lll}
\hline Organization & Number & Percentage \\
\hline Educational institutions & 84 & 95.50 \\
Other government organization & 3 & 3.40 \\
Private sector & 1 & 1.10 \\
Total & 88 & 100.00 \\
\hline
\end{tabular}

2) Analysis of the problems encountered in using information

This study focused on studying problems in the use of information by academics in the humanities and social sciences in 4 areas: 1) problems related to information resource service centers, in respect of; hardware and software, staff and search tools, 2) problems arising from academics in the humanities and social sciences themselves, 3) problems related to information in the humanities and social sciences, and 4) problems related to publishers. The results found that the participants had problems over all the areas at a moderate level. In respect of the individual areas, the participants indicated that they had problems related to the information resources of the library/information service centers at a high level (MEAN=3.60). Additionally, the problems were in respect of the modernity, sufficiency, and variety of audio-visual materials (MEAN $=4.19$ ), and real materials at a high level (MEAN =4.01) (see Table 9, 10). 
This finding is in agreement with the following studies conducted in other parts of the world, in which academics in the humanities and social sciences indicated that they could not find the information that they wanted (Tahir \& Mahmood, 2008), or that there were not enough information resources in book and journal format (De Tiratel, 2000), or that the quality of information was not sufficient (Marouf \& Anwar, 2010).

Table 9. Areas and levels of problems in the use of information

\begin{tabular}{llll}
\hline Library/Information resource service centre & MEAN & S.D. & Level of problem \\
\hline Information resources & 3.60 & 1.39 & high \\
Hardware \& software & 2.90 & 1.94 & moderate \\
Staff & 2.71 & 1.57 & moderate \\
Search tools & 2.79 & 1.54 & moderate \\
Public relations & 2.75 & 1.46 & moderate \\
\hline
\end{tabular}

Table 10. Problems in information resources encountered by academics in the humanities and social sciences

\begin{tabular}{llll}
\hline Information resources & MEAN & S.D. & Level of problem \\
\hline Printed materials & 3.17 & 1.18 & moderate \\
modernity & 2.99 & 1.16 & moderate \\
sufficiency & 3.28 & 1.19 & moderate \\
variety & 3.26 & 1.09 & moderate \\
Electronic materials & 2.86 & 1.53 & moderate \\
modernity & 2.68 & 1.64 & moderate \\
sufficiency & 2.95 & 1.62 & moderate \\
variety & 2.97 & 1.56 & moderate \\
Audio-visual materials & 4.19 & 0.93 & high \\
modernity & 4.16 & 1.04 & high \\
sufficiency & 4.22 & 0.93 & high \\
variety & 4.20 & 1.01 & high \\
Real materials & 4.01 & 2.28 & high \\
modernity & 4.06 & 2.34 & high \\
sufficiency & 4.14 & 2.26 & high \\
variety & 4.19 & 2.34 & high \\
\hline
\end{tabular}

3) Comparison of the problems encountered in using information: Testing of hypotheses

Running the t-test and F-test for analysis of the data relating to academics in the humanities and social sciences grouped by: gender, age, and education found that there were no statistically significant differences between the groups in any area of problems. However, a comparison of groups of participants according to discipline, academic role found that there were statistically significant differences at the $\mathrm{p}<.05$ level.

An interesting finding is that the academics in the humanities and social sciences indicated that they had problems with the library's public relations, and the staff's speed of services at statistically significant level of the $\mathrm{p}<.05$ level. Additionally, the social scientists had more problems than the humanities academicians in all problems mentioned above: library's public relations (social sciences, MEAN=2.51; humanities, MEAN=2.22), staff's speed of services (social sciences, MEAN=2.69; humanities, MEAN=2.26). The findings are depicted in Table 11 . 
Table 11. Comparison of problems about the information resource centers encountered by academics in the humanities and social sciences and discipline

\begin{tabular}{lllllll}
\hline & Discipline & $\mathrm{N}$ & $\bar{x}$ & $\mathrm{~S} . \mathrm{D}$. & $\mathrm{T}$ & P value \\
\hline Public relations & social sciences & 59 & 2.51 & 1.501 & .857 & $.038^{*}$ \\
& humanities & 23 & 2.22 & .998 & & \\
Speed of services & social sciences & 59 & 2.69 & 1.489 & 1.312 & $.029^{*}$ \\
& humanities & 23 & 2.26 & .864 & & \\
\hline$*=\mathrm{p}<.05$ & & & & & &
\end{tabular}

Table 12. Comparison of problems from academics in the humanities and social sciences themselves and discipline

\begin{tabular}{lllllll}
\hline & Discipline & $\mathrm{N}$ & $\bar{x}$ & $\mathrm{~S} . \mathrm{D}$. & $\mathrm{T}$ & P value \\
\hline Using library tools & social sciences & 59 & 2.36 & .943 & -1.286 & $.009^{*}$ \\
& humanities & 23 & 2.70 & 1.363 & & \\
Thinking of search terms & social sciences & 59 & 2.20 & .906 & -1.301 & $.045^{*}$ \\
& humanities & 23 & 2.52 & 1.201 & & \\
Evaluating Information & social sciences & 59 & 2.49 & 1.057 & -2.326 & $.011^{*}$ \\
& humanities & 23 & 3.30 & 2.098 & & \\
Having enough spare time & social sciences & 59 & 2.90 & 1.550 & -1.691 & $.003^{*}$ \\
& humanities & 23 & 3.70 & 2.653 & & \\
\hline
\end{tabular}

$*=\mathrm{p}<.05$

The academics in the humanities and social sciences had problems themselves in being able to think of search terms, using library tools, evaluating information, and finding enough spare time to be able to use the information available at the $\mathrm{p}<.05$ level. In addition, the humanities academicians had more problems than the social scientists in all mentioned above, using library tools; (humanities, MEAN=2.70; social sciences, MEAN=2.36), thinking of search terms (humanities, MEAN=2.52; social sciences, MEAN=2.20), evaluating information (humanities, MEAN= 3.30; social sciences, MEAN=2.49), having enough spare time (humanities, MEAN= 3.70; social sciences, MEAN=2.90) (see Table 12).

Table 13. Comparison of problems in using search tools of academics in the humanities and social sciences and academic role

\begin{tabular}{llllll}
\hline Variance & SS & Df & MS & F & P value \\
\hline Ease of use & & & & & \\
Between groups & 51.444 & 4 & 12.861 & 3.520 & $.011^{*}$ \\
Within groups & 303.372 & 83 & 3.654 & & \\
Total & 354.716 & 87 & & & \\
\hline$*=\mathrm{p}<.05$ & & & & &
\end{tabular}

Table 14. Means of problems in using search tools of academics in the humanities and social sciences and academic role

\begin{tabular}{lcl}
\hline Academic range & Scheffe test & MEAN \\
\hline Lecturer & $.041^{*}$ & 2.43 \\
Etc. (researcher) & & 5.00 \\
\hline
\end{tabular}

$*=\mathrm{p}<.05$ 
Comparison of problems in using search tools of academics in the humanities and social sciences and academic role found that they had problems using search tools in terms of ease of use at the $p<.05$ level (see Table 13). After doing the Scheffe test, it is found that there were no statistically significant differences between groups of academics in the humanities and social sciences and their different academic roles, except groups of the researchers and the lecturers. Additionally, the researchers (MEAN=5.00) had more problems than the lecturers (MEAN=2.43) (see Table 14).

The findings with regard to discipline variable are consistent with that of previous studies as reported by Marouf \& Anwar (2010) who found that the reasons why social scientists seldom used library services were the quality of the librarians and the insufficiency of the information resources. Rimmer, Warwick, Blandford, Gow, \& Buchanan (2006) also found that academics in the humanities and social sciences had problems relating to their ability to use advanced electronic search tools available in libraries. Finally De Tiratel (2000) found that academics in the humanities felt that they had difficulty in knowing about sources and problems in receiving information.

\section{Conclusion and Suggestions}

\subsection{Conclusion}

This study analyzed data collected from 3,464 citations and 88 academics in the humanities and social sciences who had published articles in 6 humanities and social science journals in Thailand. Citation analysis revealed that each article included an average of 18 citations. Books were the most frequently-cited type of documents, followed by journals, master's theses, $\mathrm{PhD}$ dissertations, websites, newspapers and research reports, interviews, and proceedings and lecture notes. The most frequently cited articles were single-author works published between 1997 and 2008. Most Thai-language documents were printed in Bangkok and published by the government, while most foreign-language documents were printed in New York and published by the private sector. The findings from survey research indicated that academics in the humanities and social sciences in Thailand have problems in using information from libraries/information resource centers at a moderate level, especially those attributable to information resources. They had problems with the modernity, sufficiency, and variety of information in audio-visual and real material formats at a high level. The findings also revealed that sex, age, education of academics in the humanities and social sciences did not significantly discriminate between problems of information usage, however discipline and academic role had statistically significant differences. In addition academics in the social sciences had more problems than academics in the humanities about the library's public relations and the staff' speed of services, on the other hand in the academics in the humanities had more problems than academics in the social sciences in accessing information by using search tools, creating search terms, and evaluating information.

\subsection{Suggestions}

This study suggests that information professionals need to help solve the problems that academics in the humanities and social sciences have in using information by increasing the amount of information in books, journals, audio-visual, and real materials relevant to their needs, and by providing workshops and making assistance available in a convenient way, such as at help desks or via email or web boards, and on Facebook or other social media. The study proposes more in-depth research on information seeking behaviors in this particular area of humanities and social sciences. Tuition and workshops in the field of information and library skills would aid the development of better use of information by academics in these disciplines. The findings of this study added to the findings of similar studies conducted in other parts of the world can create a better understanding of users' behaviors and contribute to a better theory of those behaviors.

\section{References}

Ahmadzadeh, S. (2004). Citation analysis of doctoral dissertations of civil and building discipline. Faslnameh-e-Kelab, 62, 33-47.

Arunachalam, S. (2003). Information for research in developing countries: information technology-friend or foe? Bulletin of the American Society for Information Science and Technology, 29(4), 16-21.

Baird, M., \& Oppenheim, C. (1994). Do citations matter? Journal of Information Science, 20(1), 1-15. http://dx.doi.org/10.1177/016555159402000102

Brazzeal, B., \& Fowler, R. (2005). Patterns of information use in graduate research in forestry: A citation analysis of master's theses at Mississippi State university. Science \& Technology Libraries, 26, 91-106. http://dx.doi.org/10.1300/J122v26n02_05 
Buchanan, G., Cunningham, S., Blandford, A., Rimmer, J., \& Warwick, C. (2005). Information seeking by humanities scholars. Proceedings ECDL 2005.LNCS.

Chan, L., Kirsop, N., Costa, S., \& Arunachalam, S. (2005). Improving access to research literature in developing countries: challenges and opportunities. Retrieved January 14, 2012, from http:www.ifla.org/IV?ifla71

Changkwanyeun, P. (1985). Humanities and country development. In S. Luxaninavin (Ed.), Humanities: Articles Collection (pp. 52-65). Bangkok: Faculty of Arts, Chulalongkorn University.

Chikate, V., \& Patil, K. (2008). Citation analysis of theses in library and information science submitted to university of Pune: A pilot study. Library Philosophy and Practice. Retrieved January 14, 2012, from http://www.webpages.uidaho.edu/ mbolin/chikate-patil.htm

Choinski, M. (2007). Journal use in pharmacy. Science \& Technology Libraries, 27(3), 53-64. http://dx.doi.org/10.1300/J122v27n03_04

Curtis, D. (2005). E-journals: A how-to-do-it-manual for building, managing, and supporting electronic journal collections. New York, NY: Neal-Schuman.

De Tiratel, R. (2000). Accessing information use by humanities and social scientists: A study at the Universidad de Buenos Aires, Argentina. The Journal of Academic Librarianship, 26(5), 346-354. http://dx.doi.org/10.1016/S0099-1333(00)00141-5

Delgadillo, R., \& Lynch, P. (1999). Future historians: Their quest for information. College and Research Libraries, 60(3), 245-259.

Dulle, W., Lwehabura, J., Matovero, S., \& Mulivila, T. (2004). Creating a core journal collection for agricultural research in Tanzania: Citation analysis and user opinion techniques. Library Review, 53(5), 270-277. http://dx.doi.org/10.1108/00242530410538418

Fidzani, T. (1998). Information needs and information seeking behavior of graduate students at the University of Botswana. Library Review, 47(7), 329-344. http://dx.doi.org/10.1108/00242539810233459

Garfield, E. (1979). Citation indexing: Its theory and application in science, technology, and humanities. New York, NY: Wiley.

Garfield, E. (1980). Is information retrieval in the arts and sciences inherently different from that in science? Library Quarterly, 50(1), 40-57. http://dx.doi.org/10.1086/629874

Guan, J., \& Ma, N. (2004). A comparative study of research performance in computer science. Scientometrics, 6(13), 339-359. http://dx.doi.org/10.1023/B:SCIE.0000045114.85737.1b

Haridasan, S., \& Khan, M. (2009). Impact and use of e-resources by social scientists in National Social Science Documentation Centre (NASSDOC), India. Electronic Library, 27(1), 117-133. http://dx.doi.org/10.1108/02640470910934632

Imroth, P. (1974). Humanities and its literature. In Encyclopedia of Library and Information Science (Vol. 11, pp. 71-83). New York: Marcel Dekker.

Khosrojerdi, M. (2005). Citation analysis of MA psychological dissertations of Tehran University from 2001-2006. Research on Issues of Education, 5(2), 95-114.

Kiranan, T. (2001). Social Sciences Research. Bangkok: Thammasat University.

Marouf, L., \& Anwa, A. (2010). Information-seeking behavior of the social sciences faculty at Kuwait University. Library Review, 59(7), 532-547. http://dx.doi.org/10.1108/00242531011065127

Meho, I., \& Hass, W. (2001).The information-seeking behavior of social faculty studying stateless nations: A case study. Library \& Information Science Research, 23, 5-25. http://dx.doi.org/10.1016/S0740-8188(00)00065-7

Meho, I., \& Tibbo, R. (2003). Modeling the information-seeking behavior of social sciences: Ellis's study revisited. Journal of the American Society for Information and Technology, 54(6), 571.

National Research Council of Thailand. (2011). Policies. Retrieved from http://www.trf.or.th/research/

Ortega, L. (2008). Age of references in Chemistry articles: A study of local authors' publications from selected years, 1975-2005. Science \& Technology Libraries, 28, 209-246. http://dx.doi.org/10.1300/01942620802098768 
Popoola, O. (2008). The use of information sources and services and its effects on the research output of social scientists in Nigeria universities. Library Philosophy and Practice. Retrieved January 14, 2012, from http://unllib.unl.edu/LPP/lpp2008.htm

Reunwongsa, P. (1995). Report on analysis of printed-materials of state university instructors in Thailand. Bangkok: Faculty of Science, Mahidol University.

Rimmer, J., Warwick, C., Blandford, A., Gow, J., \& Buchanan, G. (2006, June). Humanities scholars' information-seeking behavior and use of digital resources. Workshop presented at Digital Libraries in the Context of Users' Broader Activities. Chapel Hill, USA.

Seubson, P. (1989). Information Behavior. Bangkok: Student Library Science Club, Chulalongkorn University.

Sherriff, G. (2010). Information use in history research: A citation analysis of master's level theses. Library and the Academy, 10(2), 571.

Siamian et al. (2007). A Survey of information resources types used in theses of graduate students from Mazandaran University of Medical Sciences. Nama Electronic Journal, 5(3). $\mathrm{http}: / /$ www.irandoc.ac.ir/data/e_j/vol15siamian_abs.htm

Smith, T. (2003). Changes in faculty reading behaviors: The impact of electronic journals on the University of Georgia. The Journal of Academic Librarianship, 29, 192-198. http://dx.doi.org/10.1016/S0099-1333(03)00018-1

Srisawat, N. (2009). Research technique in social science. Bangkok: Publisher of Chulalongkorn.

Stone, S. (1982). Humanist scholars: information needs and uses. Journal of Documentation, 38(4), 292-313. http://dx.doi.org/10.1108/eb026734

Tahir, M., \& Mahmood, K. (2008). Information needs and information seeking behavior of arts and humanities teachers: A survey of the university of the Punjab, Lahore, Pakistan. Library Philosophy and Practice. Retrieved from http://unllib.unl.edu/LPP/lpp2008.htm

Thailand Citation Index Center. (2010). Humanities and Social Sciences Journal Database. Retrieved from http://www.kmutt.ac.th/jif/public_html/inter\%20journal.html

Thirasan, S. (2009). Writing research report technique. Bangkok: Publisher of Chulalongkorn.

Watsan-Boone, R. (1994). Information needs and habits of humanities scholars. Reference Quarterly, 34(2), 203-216.

Weintraub, J. (1980).The humanist scholars and the library. Library Quarterly, 50(1), 22-39. http://dx.doi.org/10.1086/629873

Wilson, D. (1999). Research trends in users studies: Action research and qualitative methods. Information Research, 3, 1-38.

Zainab, N., \& Goi, S. (1997). Characteristics of Citations used by humanities researchers. Malaysia Journal of Library and Information Science, 2(2), 19-36.

Zandian, F., Rezazadeh, E., \& Hassandeh, M. (2007). Citation analysis study of doctoral arts and humanities dissertations in Tarbiat Modares University. Iran: Tarbiat Modares University.

\section{Copyrights}

Copyright for this article is retained by the author(s), with first publication rights granted to the journal.

This is an open-access article distributed under the terms and conditions of the Creative Commons Attribution license (http://creativecommons.org/licenses/by/3.0/). 